a vydal zde knihu o filozofii L’udovíta Štúra, ale i řadu studií o duchovních proudech v slovenském myšlení), srovnala ho s Romanem Jakobsonem prizmatem akademických a osobních vztahů, Mária Stanková (Bratislava) promluvila o subjektivní reportáži Doroty Nvotové, Gabriela Mihalková (Prešov) zachytila ve svém vystoupení téma migrace $\mathrm{v}$ literárněvědné reflexi slovenské prózy publikované po roce 2000. Vladimíra Komorovská (Bratislava) zajímavě probrala jazykové a stylistické lapsy, Petr Kučera (Plzeň) objevně pojednal o tématu vykořenění a ztrát v současné próze na materiálu románu Jakuba Katalpy Němci (2012) a Pavol Markovič (Prešov) analyzoval mezikulturní rezonance v současné slovenské literatuře. Jana Juhásová (Ružomberok) pojednala o latenci, hyperrealismu a dokumentu na dílech slovenské spirituální lyriky po roce 2010, Milan Kendra (Prešov) se zabýval proměnou ikonografie holokaustu v díle Pavla Vilikovského, Andrea Fedorková (Košice) vystoupila s př́spěvkem K démonizácii postáv v prózach Zuzany Brabcovej a Michaely Rosovej, objektem bádání Márie Klapákové (Prešov) byla poezie jako „věc veřejná“ (populární a instagramová poezie, slam poetry) a Silvia Kaščáková (Ružomberok) udělala sondu do literatury pro děti a mládež na Slovensku po roku 2015.

Na první pohled jde o heterogenní směs témat a metodologických postupů, ale pozorný divák si povšiml, že tu jsou konstantní, stěžejní body (dětská literatura, technologicky nebo jinak nové žánry) a také dominantní metodologie programově transcendující za hranice tradiční filologie na poněkud bahnitou půdu, kde se pomalu, ale jistě ztrácí „řemeslo“ - až na výjimky. Také diskuse potvrdila značný zájem o česko-slovenské vztahy a nové literární jevy a potvrdila to, že o sobě stále víme málo. Je to více než kdy jindy hledání a někdy i nenacházení, ale nikoli bezcílné tápání, ale naopak cílené směrování do jiných sfér, často $\mathrm{k}$ bočním ziskům nebo posunům, jež jsou poměrně významné. Brněnské česko-slovenské konference se již dávno staly citlivým barometrem změn v literární vědě a české a slovenské literatuře, které jsou nejen generačního rázu, ale jsou i výsledkem obecnějších společenských změn, i když nikoli všechny budou hodnoceny pozitivně.

Ivo Pospíšil

https://doi.org/10.5817/0S2019-1-7

\title{
Za profesorem Vladimírem Svatoněm
}

Zpráva o úmrtí prof. PhDr. Vladimíra Svatoně, CSc., mne zastihla, bohužel, až po jeho pohřbu. Snad mi Vladimír prátelsky promine, že se $\mathrm{k}$ jeho odchodu vyjadřuji s odstupem až nyní, když je jeho životní dráha definitivně uzavřena. Vděčím mu za 
ulehčení mého vstupu do komunity rusistů, která ještě v dobách nekritického obdivu ke všemu ruskému hledala objektivní postoje ke skutečným hodnotám východoevropské kultury a literatury. On sám byl právě v komunitě rusistů výraznou osobností a dnes po jeho odchodu - jsme přesvědčeni, že bezpochyby v ní zanechal výraznou stopu.

Narodil se 19. července 1931 v Praze, a ačkoliv pobýval i mimo naši metropoli, byla Praha nerozlučně spjata $s$ jeho prací (po jistou dobu v bývalém Ústavu pro českou a světovou literaturu AV a poté od roku 1993 především hlavně na FF UK v Praze) - tedy na pracovištích, kde mohl uplatnit svou dominantní orientaci - rusistiku a komparatistiku. Mj. byl také vedoucím redaktorem časopisu Svět literatury. $\mathrm{K}$ jeho hlavním zájmům patřil odkaz svébytné postavy ruského romantika A. S. Puškina, nemalou pozornost věnoval dnes stále aktuálně populárnímu odkazu F. M. Dostojevského a Vladimíra Nabokova. Kromě toho neztrácel komparativní zájem o vztahy ruské literatury a kultury s celoevropským kontextem (mj. to např́klad demonstroval jeho zájem o německého spisovatele Thomase Manna nebo o nadstavbový výzkum „teorie románu“ aj.) V posledním období věnoval - jako vedoucí redaktor - výraznou pozornost výše vzpomenutému časopisu Svět literatury (redigoval jej dokonce nějakou dobu už na nemocenském lůžku).

Syntetické práce posledních let, kterými profesor Svatoň výrazně obohatil českou rusisticky a komparativně laděnou odbornou knižní produkci, rovněž nemůžeme opomenout. Hned krátce po politickém zlomu vydal v Ústavu pro českou a světovou literaturu AV ČR monografii Epické zdroje románu: z teorie a typologie ruské prózy. Monografie byla príjata $\mathrm{v}$ odborných kruzích s velkým zájmem; přiznávám se, že ještě dodnes ji doporučuji svým studentům a diplomantům. O devět let později přišla další monografie $Z$ druhého břehu. Studie a eseje o ruské literatuře. Byla poznamenána „bilančními“ pohledy autora a osobně ji řadím k velmi cenným př́spěvkům, vnášejícím řadu kompetentních poznatků a postřehů do objektivního pohledu na ruskou literaturu v kontextu literatury světové. Obě vzpomenuté monografie naznačují autorovu schopnost vzácného nadhledu a identifikace relevantních literárněhistorických jevů i chápání jevů dobově kontextových - tedy atributů, které jeho publikace řadí $\mathrm{k}$ prestižním reprezentantům nejen české literární rusistiky, ale i literární vědy obecně. Ocenili je především představitelé generaci ( $\mathrm{k}$ níž skromně řadím i sebe samotného), které vstupovaly do studia literatury (a především literatury ruské) v dobách schematicky degradovaných př́stupů ke skutečným hodnotám nejen literatury, ale kultury vůbec. Kompetentní př́stupy ke skutečným hodnotám literatury v kulturní i společenské komunitě - jak jsme si už dnes přirozeně zvykli - tedy profesor Svatoň nepochybně pomáhal prosazovat a rozvíjet. Nepovažuji za vhodné citovat rozsáhlý přehled jeho publikací, nezřídka provázených aktivním vystoupením na řadě sympozií a vědeckých konferencí v České republice, Slovenské republice i Německu, Holandsku aj. 
Podílel se rovněž záslužně na řadě prací kolektivních, zpravidla zasvěceným doslovem nebo redaktorskou úpravou, která nebyla jen jednoduchou interpretací př́padného vydání českých překladů některého ruského autora nebo prostého redakčního komentáře, ale virtuózním nadhledovým doplňkem dané publikace. Ilustrativně bych připomenul alespoň několik příkladů: Mám na mysli třeba kolektivní publikaci Na hranicích textu: úvahy a postřehy o souvislostech - mezi texty, kterou uspořádal v Ústavu slavistických a východoevropských studií v roce 2000 a doprovodil zasvěceným úvodem. Nebo informačně bohatý výbor z díla A. S. Puškina Boldinské podzimy, prezentující výbor českých překladů v pojetí Emanuela Frynty. A mohli bychom uvádět jeho zasvěcenou monografii $Z$ druhého břehu (studie a eseje o ruské literature). Odkaz jeho činnosti tak poskytuje bohatý přehled ruských autorů v konfrontaci jednak s českým, evropským - ale samozrejmě i světovým kontextem, které Vladimír Svatoň dokázal zasvěceně interpretovat a konfrontovat $\mathrm{s}$ ruskou, českou i světovou literaturou. Ale v jeho zorném úhlu se samozřejmě nenacházel jen zmíněný největší představitel ruského romantismu Puškin, ale setkáváme se mj. s takovými osobnostmi jako Michail Bulgakov, Michail Jurjevič Lermontov, Nikolaj F. Pavlov, kromě toho nadhledové analýzy literatury „přelomových“ období jako byl třeba Arkadij Averčenko, nebo jeho studie a analýzy vývojových etap ruské a evropské literatury - zpravidla doprovázené respektováním „kontinuity“ jejího vývoje. V této souvislosti bychom mohli zmínit některé poslední práce, které vznikly ve spolupráci s Annou Houskovou (mám na mysli např́klad práci Literatura na hranici jazyků a kultur, nebo spolu s Oldřichem Králem a Martinem Procházkou Kontext, preklad, hranice: studie $z$ komparatistiky. S Annou Houskovou připravil např́klad i další studie „Z komparatistiky III“ pod názvem Kultura a místo nebo Pokusy o renesanci Západu: literární a duchovní východiska na přelomu 19. a 2o. století. Ve spolupráci s Jiřím Honzíkem, který se staral o překlad a vysvětlivky, připravil publikaci Poraněné sny - Vladimir Odojevskij. Doslovem a výběrem textů se podílel na vydání odkazu Arkadie Averčenka Procházka $v$ kopriviách - tedy autora, který měl velmi blízko ke kultuře české. Nebo můžeme připomenout jeho práci Proměny dávných príběhư: o poetice ruské prózy, podobně jako jeho úvahy o srovnávací literární vědě Román $v$ souvislostech času a mnoho dalších.

S obdivem jsem sledoval Vladimírův široký pracovní obzor a kompetentní znalosti, s nimiž sledoval a komentoval vývoj literární vědy a korigoval diskuse v řadě odborných společností (jen ilustrativně vzpomenu Českou asociaci rusistů, Společnost Mariny Cvetajové, Literárněvědnou společnost, Estetickou společnost, Kruh moderních filologů, členství poroty pro udělování ceny Magnesia Litera... Vedle toho třeba dokázal být autorem řady hesel z ruské literatury $\mathrm{v}$ edici tzv. Malá československé encyklopedie... 
Kdybychom chtěli v tomto stručném nekrologu (de facto jen ilustrativním výčtu) naznačit všechny publikační počiny profesora Vladimíra Svatoně, byl by náš seznam mnohem větší. (Přímo se nabízejí ještě tituly jako Proměny dávných prúběhů (O poetice ruské prózy) či Román $v$ souvislostech času. Úvahy o srovnávací literární vědě nebo Na cestě evropským literárním polem. Studie z komparatistiky 욤 nebyl by stejně náš výčet vyčerpávající. Nicméně by nepochybně akcentoval rozměry ztráty, kterou česká kultura úmrtím profesora Svatoně utrpěla. Jsem ale přesvědčen, že v řadě kolegů badatelů i studentů a zájemců o kompetentní studium literatury nebude jeho jméno zapomenuto.

Čest jeho památce.

Oldřich Richterek 
